\title{
Impact of the COVID-19 Pandemic on the Financial Well-being among Older Adults in Malaysia
}

\author{
"Muhammad Amjad Khan' \\ Khor Saw Chin ${ }^{1}$ \\ Charles Ramendran SPR ${ }^{1}$
}

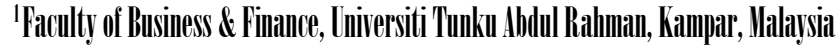

The purpose of this study was to explore the impact of the COVID-19 pandemic on the financial well-being among older adults in Malaysia. The study was carried out a literature review to evaluate research published in journals and conference proceedings in Malaysia relating to older adults. The study applied personal control theory to evaluate the CovID-19 pandemic's impact on the financial well-being among older adults in Malaysia. The findings of this study demonstrated that older adults lost their source of income during the COVID-19 pandemic that has adversely affected their financial well-being. This study contributes to shape a sustainable society by offering constructive knowledge of the financial well-being of older adults as they were a more vulnerable portion of society in the COVID-19 pandemic. The study concluded that policymakers should develop effective social security policies to absorb financial shocks so that the lifestyles of older adults can be improved.

Keywords: COVID-19, pandemic, older adults, financial wellbeing, Malaysia

JEL: E24, II5, I38
\end{abstract}

The COVID-19 has caused tremendous terror and misery among older adults worldwide. The studies conducted in the United States, China, India, and Malaysia revealed that more than 60 percent of older adults patients died due to the COVID-19 pandemic (Jantan et al., 2020). Older adults had faced adverse effects of COVID-19 all over the world including Malaysia (Mustaffa et al., 2020).

As of 6 June 2021, the Ministry of Health (2021) announced that 60 out of 87 COVID-19 deaths reported in Malaysia were older adults. The reason being a majority of vulnerable older adults have chronic illnesses such as diabetes, hypertension, renal disease, heart disease etc. (Lloyd-Sherlock et al., 2020). The other cause of deaths of older adults was being infected by asymptomatic COVID -19 visitors who unknowingly spread the disease to the older adults.

To reduce the number of COVID-19 cases in Malaysia, the government closed the borders on the 18th of March and enforced Movement Control Order (MCO) nationwide (Shah et al., 2020). This enforcement has been done with the hope of breaking the deadly virus transmission chain by urging older adults to stay at home and reduce outdoor activities. As per the World Health Organization (WHO) recommendations, masks and gloves should be worn by all including older adults (World 
Health Organization, 2020).

COVID-19 not only affects older adults from a health point of view but also impacts their financial life (Harper, 2021). One of the major concerns of the government and policymakers is the financial well-being of older adults. The results of the 2019 Gallup poll revealed that about one-fifth of Americans had no savings for the future and three-quarters of respondents were pessimistic about their financial situation. The subsequent Gallup poll in 2021 showed more than half of Americans were concerned about not having sufficient funds during retirement, and the other half of respondents were worried about not being able to maintain a preferred lifestyle.

The United Nations Development Programme (UNDP) Malaysia carried out the Rapid Assessment on Household Income Survey (RaHIS), it was found that among households with older adults, COVID19 has reduced 50 percent of the household income of 37.1 percent older adults in Malaysia (United Nations Development Programme, 2020). This may imply more older adults have lost their source of income than younger people. Older adults are more affected by the COVID-19 in terms of household income. The survey showed that 29.1 percent of older adults' households may not have enough supply of food and other necessities for next week's use. It shows that older adults are a more vulnerable age group in Malaysian society during pandemic.

\begin{tabular}{ll}
\hline Sources & Liabilities \\
\hline Wage & Car loans \\
Business & Housing loans \\
Pension & Personal loans \\
Rental & Credit card loans \\
Children & Non-bank loans \\
Agriculture & \\
Dividend & \\
Bonus & \\
Annuity & \\
Others & \\
\hline Source: Masud and Haron (2008), AKPK (2018)
\end{tabular}

Table 1. Sources of Income and Financial Liabilities of Older Adults in Malaysia

Despite the aforementioned few surveys, the impacts of COVID-19 on the financial well-being of older adults in Malaysia have been insufficiently investigated. The main aim of this study is to provide in-depth and up-to-date literature on the impacts of COVID-19, particularly on the financial wellbeing of older adults in Malaysia. Hence this study fills this literature gap. The novelty of this study is the discussions on how the financial well-being of older adults in Malaysia is being compromised. The 


\section{Khan et al.}

findings from the previous studies on the financial well-being of older adults may not be consistent with the findings of the current studies due to the effects of COVID-19. Gerontologists, other researchers and policymakers investigating COVID-19 and its impacts on economy will benefit from this literature to develop a framework and policies relating to older adults.

This current literature review followed the steps as outlined by Green et al. (2006) to evaluate the secondary research published in journals and conference proceedings.

\begin{tabular}{|c|c|c|c|}
\hline Database & $\begin{array}{c}\text { Years } \\
\text { Searched }\end{array}$ & Search Terms & Strings of Terms \\
\hline Scopus & $2020 / 2021$ & $\begin{array}{l}\text { COVID-19, pandemic, older adults, } \\
\text { financial well-being, Malaysia }\end{array}$ & $\begin{array}{c}\text { Financial well-being, older adults, } \\
\text { Malaysia AND pandemic }\end{array}$ \\
\hline PubMed & $2020 / 2021$ & $\begin{array}{l}\text { Pandemic, older adults, financial well- } \\
\text { being, Malaysia }\end{array}$ & $\begin{array}{c}\text { Older adults, financial well-being, } \\
\text { Malaysia AND COVID-19, }\end{array}$ \\
\hline $\begin{array}{l}\text { Web of } \\
\text { Science }\end{array}$ & $2020 / 2021$ & $\begin{array}{l}\text { Malaysia, pandemic, older adults, } \\
\text { financial well-being, }\end{array}$ & $\begin{array}{l}\text { COVID-19, older adults, financial } \\
\text { well-being AND Malaysia }\end{array}$ \\
\hline ERIC & $2020 / 2021$ & $\begin{array}{l}\text { Older adults, financial well-being, } \\
\text { Malaysia, COVID-19, }\end{array}$ & $\begin{array}{c}\text { Pandemic, older adults, financial } \\
\text { well-being AND Malaysia }\end{array}$ \\
\hline ScienceDirect & $2020 / 2021$ & $\begin{array}{c}\text { Financial well-being, older adults, } \\
\text { Malaysia, pandemic }\end{array}$ & $\begin{array}{l}\text { Malaysia, pandemic, older adults } \\
\text { AND financial well-being, }\end{array}$ \\
\hline
\end{tabular}

Table 2. Literature Search Sheet

\section{LITERATURE REVIEW}

COVID-19 pandemic has imposed new challenges on economic, socio-economic, health, well-being and its adverse impact has surpassed other pandemics that occurred in the past (Gilbert, 2020). Since the beginning of the COVID-19 pandemic, increased sensitivity has been developed among older adults. They are facing dual challenges, one from health and the other from financial security (Chhatwani, 2021) as both are interconnected. In healthcare expenditures, older adults bear a high financial burden due to increased medication costs as they require greater medical attention. They need more savings to face unavoidable and uncontrollable circumstances, particularly for Malaysians, whose life expectancy has risen to 75 years (Lim et al., 2021). Therefore, they are considered the more vulnerable portion of the society in the current COVID-19 pandemic.

The general well-being literature is predominantly based on subjective well-being theories (Diener, 2009). Diener (1984) gave an overview of the field of subjective well-being. However, theories from different disciplines such as economics, psychology and sociology shed light on the financial wellbeing literature. For example, (Lim et al., 2021) adopted the life cycle theory and mental accounting theory to assess whether income level, economic condition, saving behavior and retirement goal clarity affect employees' retirement saving behavior during the COVID-19 pandemic in Malaysia. Xue et 
al. (2020) applied Item Response Theory (IRT) to develop a Financial Literacy Index (FLI) to investigate how financial literacy by itself and via interaction with consumption patterns, affects elderly Australians' financial well-being.

Rahman and Shafiai (2021) used family resource management theory to determine the factors that affect the financial well-being among young employees in Malaysia during movement control order (MCO). Yeo and Lee (2019) adopted social capital theory to understand the association between perceived financial well-being and life satisfaction among older adults. Chhatwani (2021) used the theory of personal control to examine the linkage between a sense of personal control and financial well-being among the elderly during COVID-19. This study adopts the theory of personal control to explore the impact of the COVID-19 pandemic on the financial well-being among older adults in Malaysia.

Personal control is "the perception of oneself as an effective person" which perseveres in producing positive outcomes and avoiding negative outcomes (Ross and Broh, 2000). According to the theory of personal control (Ross, 1989), individuals who have a high level of personal control are more likely to put in more effort, be more motivated and persevere, resulting in several positive consequences such as improved health (Mirowsky and Ross, 1998), better academic results (Ross and Broh, 2000), and increased earnings (Ross and Sastry, 1999). Financial hardship results from a lack of control over one's finances and many of these issues can be prevented by taking proactive actions to improve one's financial situation and protect one's financial future. People who have a strong sense of personal control are more motivated to take charge of their financial situation and engage in proactive financial actions that help to increase their financial well-being.

\section{COVID-19's Economic Hit on Malaysia}

The COVID-19 pandemic has affected the global and domestic economies. During the MCO period, it was observed that social and recreational activities have been reduced continuously and it has also reduced the consumption and investment cycle of the economy. Due to these dampened market activities, the household income of older adults has reduced (Aziz et al., 2021). Bank Negara Malaysia (2020) estimated the GDP growth of 0.7 percent for the first quarter of 2020 , as opposed to 4.5 percent for the same quarter in 2019. This shows the severe impact of the MCO on the Malaysian economy.

This movement restriction has led to the slowing of the economy as demand plummets. With the plummeting of the economy, many businesses were forced to close and their workers had to left jobless. The shutdown of the economy has brought job and income loss, exposing the ever-growing Inequality in terms of the financial gap among the country's richest and poorest people (Hasanat et 


\section{Khan et al.}

al., 2020). The main obstacle is how the different remedies can reach the most vulnerable groups who need help and if relief could be provided within the shortest time as well as how is the economy able to recover and increase the plummeting employment rate in the long term (Shakeel et al., 2020).

The problem with the restrictive movement order is that the stimulus plans will not be able to sustain the businesses for long if the businesses wouldn't resume operations. During the $\mathrm{MCO} / \mathrm{CMCO}$, it is claimed that RM35 billion was lost per month and RM2.4 billion every day due to the reduced economic activities (Hasimi, 2020). Zainul (2020) referred to the report of the Malaysian Institute of Economic Research (2020) which mentions that about 15 percent of jobs were lost out of 16 million and household income was estimated to lose RM95 billion, a reduction of 12 percent from the projected baseline in 2020. The World Bank has cautioned that Malaysia has limited budgetary to face further implications of the pandemic or extended limits on the overall economic activity (World Bank, 2020).

\section{COVID-19's Socio-Economic Impact on Older Adults}

According to an online survey and phone interview carried out during MCO by the UNDP-led Rapid Assessment on Household Income Survey (RaHIS) between March and May 2020, 33 percent of the older adults in Malaysia claimed that COVID-19 is impacting their socio-economic status (United Nations Development Programme, 2020). One-third of the nation's older adults suffered from the adverse effects of the deadly infectious virus COVID-19. Even if older adults have a large income, there is no guarantee they will be financially secure in the long run.

Social Wellbeing Research Centre (2021) published key findings of the Malaysia Ageing Retirement Survey (MARS) which was carried out in 2018-2019; 40 percent of older adults aged 60 years and above participated and shared their financial, social and health-related issues such as work, employment, retirement, income, relationship with spouse, parents, children, siblings, transfers, health status, diagnosed illness, healthcare utilization, physical measurement, etc. In Malaysia, chronic illnesses such as diabetes, hypertension, renal disease, heart disease, and other disorders accounted for 80 percent of COVID-19 fatalities and 2.1 million older adults have been badly affected by the COVID19 pandemic (Lim, 2020).

In terms of health, older adults are at greater risk from severe viral complications and also have reduced access to other healthcare facilities (Mustaffa et al., 2020). It is found that 42 percent of older adults faced difficulty receiving healthcare as shown in Figure 1. It shows that COVID-19 also exposed the hitches of the healthcare system. Due to the pandemic, the healthcare system in Malaysia has enforced standard operating procedures (SOPS) for public, thus cutting down the number of patients in hospitals. The increase in the number of COVID-19 patients across the nations has also 
reduced the access to healthcare for other co-morbid illnesses such as diabetes, high blood pressure, kidney failure which are more prevalent among older adults.

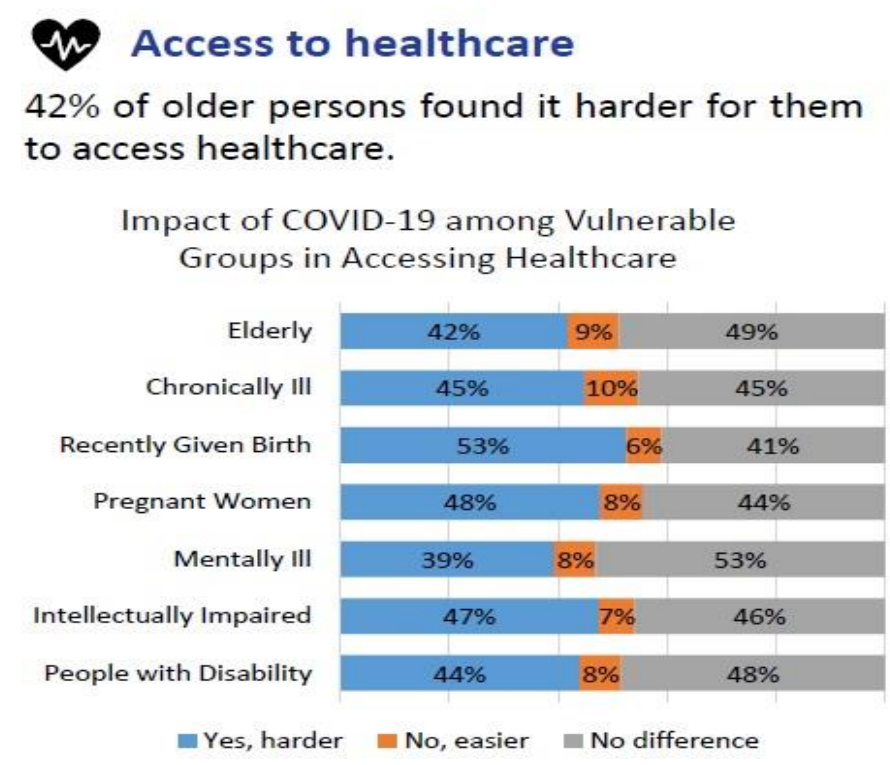

Source: UNDP Rapid Assessment on Household Incomes Survey (RaHIS)

Figure 1. Access to Healthcare

Results from Malaysia Active Retirement Survey (MARS) show that 78.6 percent of older adults received outpatient medical treatment from the government facility or practitioner (Figure 2). This figure has overwhelmed the government health facility, increasing the burden on the shoulder of the government facilities during COVID-19. One of the reasons suspected is the financial capability of older adults has been severely reduced, therefore, they had no choice but to go for treatment in the subsidized government health facilities which require lower fees as opposed to private health practitioners.

COVID-19 pandemic affects the socioeconomic status, household income, food and other necessities as well as the healthcare system for older adults. COVID-19 has also affected the development of negative behaviour of older adults. 24.6 percent of older adults have been associated with an increase in tobacco or alcohol consumption. COVID-19 also affects the physical activities of older adults as they were found to display physical aggression in their behaviors. This pandemic also increased the mental tension among older adults in the household. Older adults were also found with the symptoms of depression due to COVID-19. Furthermore, COVID-19 also becomes a cause of psychological distress among older adults (United Nations Development Programme, 2020).

Older adults are at higher risk among people of all ages to have serious problems and succumb to 


\section{Khan et al.}

\section{(}

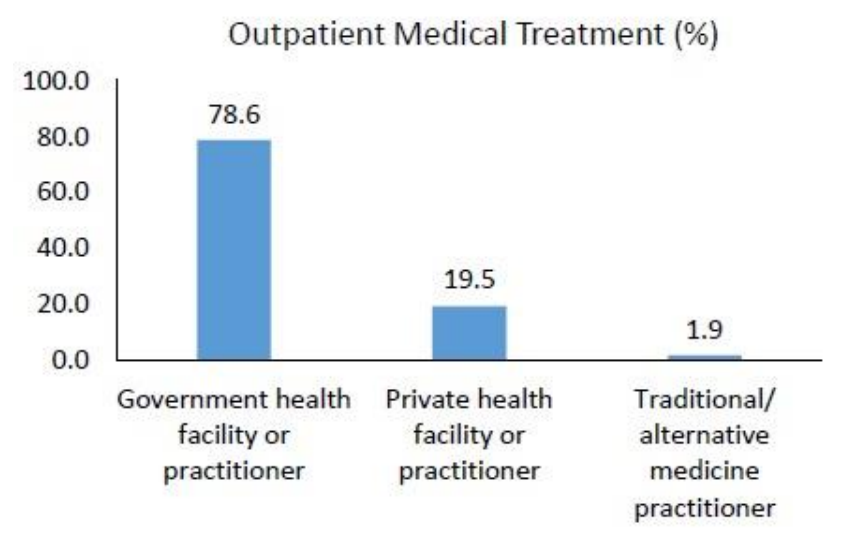

Source: Malaysia Active Retirement Survey

Figure 2. Outpatient Medical Treatment

them if they contract the disease. This is because older adults have physiologically associated with ageing and other underlying co-morbidities issues (Ooi et al., 2021). Besides the usual ageing issues, older adults also face additional risks in terms of health and socioeconomic risks. Prolonged isolation from society can severely affect older adults who live alone and whose sole contact is through work or other social activities (Pazim et al., 2021). These social activities may comprise community venues and worship places, which may not be accessible during the movement control period.

Isolated older adults who are living alone suffer the most risk, in particular those without close friends and family nearby or those who are not digitally connected to their friends and relatives (Xie et al., 2020). They are usually the ones who heavily rely on social or voluntary services, which may be impeded during enforcement of the movement control order. Social isolation can cause older adults to be at risk of depression and other mental health problems. Additionally, if they are cut from food and other essential medication supplies, they are most likely to suffer from severe physical health issues, making older adults among the most marginalized communities in the face of this viral pandemic. Long-term isolation from close family members and friends could lead to a tense relationship between older adults and loved ones (Lai et al., 2016).

\section{COVID-19 and Financial Well-being of Older Adults}

According to the Social Wellbeing Research Centre (2021), 80.3 percent of older adults who are 60 years old and above are found to be living with other family members, while 14.9 percent are living 
with their spouse. The rest 4.8 percent of older adults are living alone as shown in Figure 3 . This shows the majority of older adults are probably dependent on the other family members as they are financially weak and unable to support themselves. It means their financial well-being is very low which does not allow them to live with financial liberty.

In terms of family support, there are two categories of older adults. They either receive support from family or give support to the family. 22.9 percent of older adults, who normally receive financial supports from other family members, declared that they could not get family support due to COVID19. It shows that family members were not able to take care of their older adults due to COVID-19 as it has badly affected their financial resources which ultimately affected the older adults.

On the other hand, older adults, who normally supported their families, were more affected due to COVID-19. About 52.7 percent admitted they could not support their families during COVID-19. It shows COVID-19 has badly affected their financial power and resources; therefore, older adults are unable to financially help their families. It shows COVID-19 affected older adults in both ways, either receiving help from a family member or giving help to the family members.
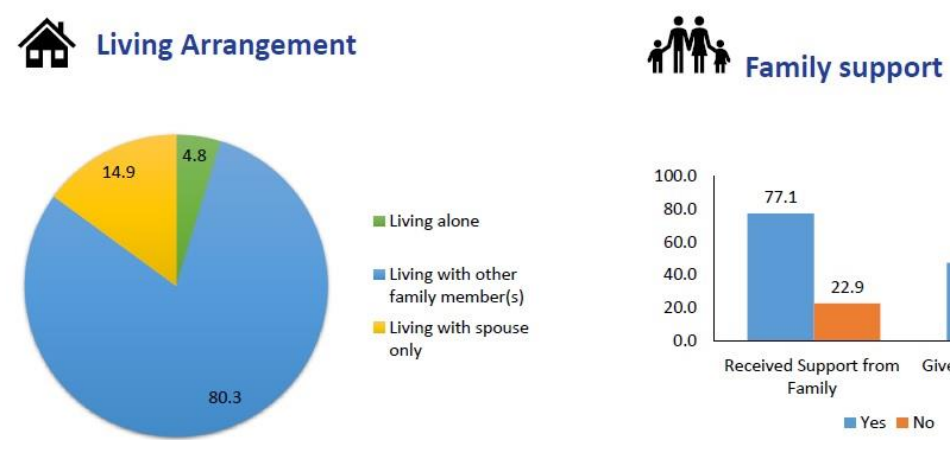

Source: Social Wellbeing Research Centre (SWRC)

Figure 3. Living Arrangement and Family Support

Domestic older adult helpers are considered high-risk front-liners as their work demands them to work in others' homes and have close contact with the virus. They lack protection from infectious disease and are usually subjected to the employers' demands. Informal sectors such as wholesale, retail trade, repair of motor vehicles, manufacturing, food services and real estate have been highly impacted by the COVID-19, where most older adults work. According to the International Labour Organization (ILO) estimates, about 1.6 billion informal employees who stand about 76 percent of all the informal employment are severely impacted by the restricted movement orders (Sandanasamy et al., 2020). Older adults are more vulnerable to financial shocks from COVID-19.

Informal workers usually lack access to healthcare facilities and are unable to replenish their income 


\section{Khan et al.}

in the event of illness or restricted movement. Many older adults do not have the option to work from home, with some remaining at home could mean the potential of losing their employment. Without any source of income, these older adults practically live from hand to mouth or even starve (UN News, 2020).

Older adults are among the most vulnerable as they are facing difficulty in maintaining their financial resources, health, and welfare during a COVID-19 pandemic. The unemployment rate escalated from May 2021 at 4.5 percent to 4.8 percent in June 2021. The number of unemployed increased from 728.1 thousand persons to 768.7 thousand persons. The largest reduction was witnessed in the services sector such as accommodation, food and beverages services, real estate, wholesale, and retailers (Department of Statistics Malaysia, 2021).

The labor force participation rate (LFPR) declined from May 2021 at 68.5 percent to 68.3 percent in June 2021. The number of labor force dropped from 16.10 million persons to 16.07 million persons. Labor force participation rate (LFPR) reflects that was the first decline recorded in the labor force since the COVID-19 pandemic stroke the country in April 2020 (Department of Statistics Malaysia, 2021).

Street vendors, daily income earners such as small retailers, hawkers, sellers in markets and stalls as well as smallholders, and market traders consist of a fair share of older adults. As practicing social distancing in congested public spaces is difficult to be achieved, these businesses had to be temporarily halted to contain the widespread infection (Department of Statistics Malaysia, 2021). The reduced sales and a loss of perishable goods have resulted in accumulation of debts. Their well-being is further complicated with the older adults-stay-at-home rules enforced, which have led to domestic violence (United Nations, 2020).

The COVID-19 pandemic has an impact on the older adults income and they are compelled to spend more such as groceries, pharmacies, household supplies; in term of soap, detergent, hand sanitiser, face masks, wipes, as compared to pre-pandemic, hence COVID-19 pandemic adversely affected older adults saving capabilities. Other sources of income are also diminishing like a fall in the interest rates of fixed deposits, a drop in the stock prices and unit trust prices, economic activity slow down and goods become more expensive which badly affect the EPF retirement savings of older adults (Lim et al., 2021).

The older adults' mental health, physiological sickness, and early mortality are all linked to a lack of financial resources (Matthews et al., 2005). As older adults face many uncertainties regarding their lifespan, health-related difficulties, and expected financial needs, making it difficult for them to decide between spending and saving (Asebedo et al., 2019).

The poor and the most vulnerable older adults do not have access to financial loans and keep limited savings. However, as the country is already facing major financial difficulties, injecting 
economic stimulus to help older adults is a burden on the government at the moment. COVID-19 troubled the financial life of older adults. As a result of the viral pandemic, older adults have had considerable financial troubles (Povera, 2020). Following that, on March 27, 2020, the Malaysian government unveiled the Prihatin Rakyat Economic Stimulus Package (PRIHATIN) to help soften the financial impact on citizens. The Ministry of Finance Malaysia (2021) had announced RM 25 million as financial support to the older adults, including cash distribution, healthcare services, and food items, as well as RM 250 for individual government pensioners. It is unknown how long the COVID-19 pandemic will continue (Adhikari et al., 2020) and its adverse effect on the financial well-being of older adults. A synoptic view of reviewed literature is presented in Table 3 (see Appendix-I).

\section{DISCUSSION}

This study explored the impact of the COVID-19 pandemic on the financial well-being of older adults in Malaysia supported by the theory of personal control (Ross, 1989). This theory explains that individuals who have a high level of personal control have high earnings and improved health. Individuals who demonstrate a lack of personal control result in financial loss and health that in turn negatively impact their financial well-being.

The financial well-being of older adults during the COVID-19 pandemic has been affected as per the literature reviewed in the previous sections. Older adults were found to have less control over their savings. This study could not observe a positive relationship between economic condition and older adults' retirement savings. These findings are inconsistent with the prior studies that indicate economic condition positively affects retirement savings (Goda et al., 2012). The reason is Employee Provident Funds (EPF) would be insufficient for retirees during COVID-19 to live comfortably after retirement (Ali et al., 2020). During the COVID-19 pandemic, older adults could not control their savings because they had to spend extra money on health-related expenses and household items. To buy assets and to pay for children's education, the EPF organisation permits to withdraw the funds at the age of 55 (Ali et al., 2020; Foziah et al., 2018). However, such withdrawals reduce the post-retirement rewards and leave substantial negative outcome on the financial well-being of older adults. This is another reason for a lower level of personal control over finances.

The positive impact of income level also improves the financial well-being of older adults. However, this study found that COVID-19 has a pessimistic impact on older persons' income as their employers' cut pay and do not give any increment when they need to spend more time at home due to COVID-19 restrictions. Older adults also had no control over other sources of income as they were diminished in the COVID-19 pandemic such as a fall in the interest rates of fixed deposits and stock as well as unit 


\section{Khan et al.}

trust prices (Lim et al., 2021). These findings are consistent with the study of Brown et al. (2020), in which they explained that since the COVID-19 pandemic was officially declared, economic activities were also disturbed and investors bore an immediate loss in risky assets such as stocks. Hence, older adults could not control their savings and encounter loss in other sources of income.

Older adults faced more financial challenges during the COVID-19 pandemic as home-based workers. Home-based older adult workers are the ones seriously affected by decisions made by the huge conglomerates. As the tourism industry halts following the government order, the demand for handmade crafts made especially for the tourists and export market plummeted, severely affecting the home-based craft workers. Other factors such as the inability to buy raw materials, the increase in production material price, and prolonged debtor repayment period all bring huge effects to these home-based older workers (Lim, 2020). Hence, the COVID-19 pandemic negatively impacted the financial wellbeing of older adults and such external factors are out of their control.

Older workers, due to their age, are at a higher risk of discrimination. In this crisis, some businesses attempt to reduce their expenses by retrenching the older employees who usually have higher salaries. Another concern is that employers may want to avoid the risks of compensating their older adult workers if they fall ill. The unpleasant truth is the older workers who lose their jobs now will unlikely be employed again. Companies and businesses may shun them for their reduced agility. The spread of infection, job loss, income reduction, lockdowns, and physical movement restrictions all contributed to a loss of control over the external situation during the COVID-19 (Alvarez et al., 2020).

This study revealed that the COVID-19 pandemic is a significant cause of low financial well-being among older adults in Malaysia, which could lead them towards poverty. These findings are also supported by the International Labor Organization (ILO) stating that the most vulnerable groups outlined are older adults in the informal economy, where they faced the most unfavorable effects of COVID-19. Older adults have less control to handle this situation. These poor older adults receive income that falls below a given poverty line due to low-income jobs (Lim, 2020). Without help from the government or family, their chances of falling into poverty are high. This study identified the reasons for the low financial well-being of older adults and their control over issues. These findings may equip older adults to secure a better financial future.

\section{CONCLUSION}

The COVID-19 pandemic has brought greater challenges and threats to humanity than ever before, especially to older adults' financial well-being. The impact of COVID-19 on the financial well-being of older adults is highlighted in this study. This study added to the body of knowledge about psychologic- 
al determinants of financial well-being and explained personal control matters during difficult times. This study found financial well-being of older adults had reduced during the COVID-19 pandemic. Setting small financial goals for them to achieve may help older adults in gaining personal control over finances. In addition, policymakers should develop effective policies to promote the financial wellbeing of older adults during COVID-19. Nevertheless, this study contributes to a sustainable society by offering a constructive knowledge of the financial well-being of older adults, who are a vulnerable portion of society in the COVID-19. Thus far, limited literature is available on the impact of COVID-19 on financial well-being among older adults. Hence, it is urgent to pay attention to the disrupted lives of older adults, especially in terms of their financial well-being.

\section{IMPLICATIONS}

The findings of this study have shown that policies of different time frames such as immediate, recovery and longer-term should be developed. Prompt action is urgently needed for older adults to access healthcare facilities so that older adult workers do not lose their jobs and have a secure income. Once the pandemic ends, efforts should be focused on an employment plan for recovering the affected older adults' job market.

To recover in the long-run and be equipped for similar future economic shocks, there is an urgent need to form a more resilient and inclusive economy, to protect vulnerable older adults. Therefore, there is the need to address the current weaknesses in the institutional structure and to address issues faced by older adults. In the short-term plan, there should be both health and economic assistance programmes, especially for older adults. Older adults' financial well-being and welfare must be included in the nation's priority plan. In times of quarantine and isolation, older adults require secure access to healthy food, basic supplies, and financial assistance for their financial well-being.

It is important to ensure older adults receive clear instructions on how to stay mentally and physically well during the pandemic. Accurate information should be appropriately disseminated so that they are not misled. It should be ensured that older adults are taking counselling from their financial advisers during the COVID-19 outbreak to share their worries and receive assistance from professionals in making decisions that are consistent with their financial goals. Policies that can provide better health and financial benefits to older adults should be developed.

A majority of retirees $(51 \%)$ believe that the current pension system needs to be improved, to improve the quality of life for older adults, as they were dissatisfied with the minimal benefits from the pension system particularly those with low-paying employment (Ali et al., 2020). EPF is still insufficient to provide a retiree's financial security after retirement and older adults had no other savings (Ubaidilla- 


\section{Khan et al.}

h et al., 2020). The lack of a systematic social care system indirectly impacts the financial well-being of older adults (Aziz et al., 2021). This situation required full attention from multiple parties to protect the rights and needs of older adults. The low returns on EPF would not be enough to cover living expenses and pay the high medical bill. There is a pressing need to develop a comprehensive social security system as Malaysia is going to enter aged country status by 2030 . That system could improve the lifestyle of older adults and help them to absorb any financial shocks. The government and policymakers should tighten the contributors' eligibility for pre-retirement withdrawals. Furthermore, financial planners can evaluate the role of personal control and personality traits while providing financial advice to older adults. Policymakers and employers should pay attention to psychological processes that increase personal control in people approaching retirement. These useful findings can help Malaysian policymakers to improve the current social security and pension system policies.

\section{LIMITATIONS AND FUTURE DIRECTIONS}

This study aimed to provide insights into the financial well-being of older adults during COVID-19 from a developing country perspective, however, the study's limitations should be acknowledged. As the study is limited to Malaysia, the findings should be interpreted with caution, even if they are likely to be relevant and applicable to other developing countries. Future studies can compare the pre-pandemic and post-pandemic financial well-being of older adults to understand the effects of COVID-19 on the financial well-being of older adults. More research is needed to further understand the multidimensional nature of COVID-19's effects on older adults' poverty, unemployment and inequality.

\section{REFERENCES}

Adhikari, S. P., Meng, S., Wu, Y. J., Mao, Y. P., Ye, R. X., Wang, Q. Z., Sun, C., Sylvia, S., Rozelle, S., \& Raat, H. (2020). Epidemiology, causes, clinical manifestation and diagnosis, prevention and control of coronavirus disease (COVID-19) during the early outbreak period: A scoping review. Infectious Diseases of Poverty, 9(1): 1- 12. https://doi.org/10.1186/s40249020-00646-x

AKPK. (2018). Financial Behaviour for Quality Lifetime. Symposium Financial Behaviour For Quality Lifetime, 1- 40. Retrieved December 4, 2021, https://power.akpk.org.my/FEPVirtual/UAT/Temp/publication/20191211170131_AKPK Financial Lietracy Synposium 2018 Conference Proceedings.pdf

Ali, I., Azman, A., Hatta, Z. A., Islam, M. R., \& Hussain, A. H. M. B. (2020). Is Malaysia's pension scheme sufficient to secure the quality of life for the elderly? Social Work and Society, 18(2): 1- 19

Alvarez, F. E., Argente, D., \& Lippi, F. (2020). A simple planning problem for covid-19 lockdown. National Bureau of Economic Research. 1- 26. https://doi.org/ 10.3386/w26981

Asebedo, S. D., Wilmarth, M. J., Seay, M. C., Archuleta, K., Brase, G. L., \& MacDonald, M. (2019). Personality and saving behavior among older adults. Journal of Consumer Affairs, 53(2): 488- 519. https://doi.org/10.1111/joca.12199

Aziz, N. A. B., Mustapha, S. Z., Hassim, N. H., \& Shaari, N. F. (2021). Improving social security among older persons in Malaysia during Covid-19 by applying best practices from other countries. International Journal Academic Research in Business and Social Sciences, 11(8): 1568- 1578. https://doi.org/10.6007/IJARBSS/v11-i8/10685

Bank Negara Malaysia. (2020). Economic and financial developments in Malaysia in the first quarter of 2020. Retrieved December 4, 2021, https://www.bnm.gov.my/publications

Brown, G., Knoll, C., \& Kuhnen, C. (2020). Can I ever retire? The effects of COVID-19 on financial security. Retrieved December 7, 2021, https://kenaninstitute.unc.edu/kenan-insight/can-i-ever-retire-the-effects-of-covid-19-on-financialsecurity/ 
Chhatwani, M. (2021). Personal control and financial well-being among the elderly: Moderating role of the big five. Personality and Individual Differences, 184, 1- 5. https://doi.org/10.1016/j.paid.2021.111171

Chung, C. F., Rebecca, T.S., Singau, J. B., Pazim, K. H., \& Mansur, K. (2020). The repercussions of Covid-19 pandemic on the wellbeing of older people in Malaysia: A literature review. International Journal for Studies on Children, Women, Elderly, and Disabled, 11(10): 17- 23.

Department of Statistics Malaysia. (2021). Key statistics of labour force of Malaysia, June 2021. Retrieved December 10, 2021 , https://www.dosm.gov. my/v1/index. php? r=column/cthemeByCat\&cat=124\&bul_id=SkFRMTJ0d1RIR3BrdG1aUTBsUmw2Zz09 \&menu_id=Tm8zcnRjdVRNWWIpWjRIbmtlaDk1UT09

Diener, E. (1984). Subjective well-being. Psychological Bulletin, 95, 542- 575.

Diener, Ed. (2009). Subjective well-being. In The Science of Well-Being (pp. 11- 58). Springer, Dordrecht. Retrieved December 4, 2021, https://doi.org/10.1007/978-90-481-2350-6_2

Foziah, N. H. M., Ghazali, P. L., Mamat, M., Salleh, F., Guci, D. A., Jaaffar, S. A. S., Mahmud, M. S., \& Yazid, A. S. (2018). Viability of annuity-based option as retirement form of benefit among EPF retirees. International Journal of Engineering \& Technology, 7(3.28): 191- 193.

Foong, H. F., Haron, S. A., Koris, R., Hamid, T. A., \& Ibrahim, R. (2021). Relationship between financial well-being, life satisfaction, and cognitive function among low-income community-dwelling older adults: The moderating role of sex. Psychogeriatrics, 21(4): 586-595.

Gilbert, G. L. (2020). Commentary: SARS, MERS and COVID-19-new threats; old lessons. International Journal of Epidemiology, 49(3): 726- 728. https://doi.org/10.1093/ije/dyaa061

Goda, G. S., Shoven, J. B., \& Slavov, S. N. (2012). Does stock market performance influence retirement intentions? Journal of Human Resources, 47(4): 1055- 1081. https://doi.org/10.3368/jhr.47.4.1055

Green, B. N., Johnson, C. D., \& Adams, A. (2006). Writing narrative literature reviews for peer-reviewed journals: secrets of the trade. Journal of Chiropractic Medicine, 5(3): 101- 117. https://doi.org/10.1016/S0899-3467(07)60142-6

Harper, S. (2021). The impact of the Covid-19 pandemic on global population ageing. Journal of Population Ageing, 14, 137142. https://doi.org/10.1007/s12062-021-09330-w

Hasanat, M. W., Hoque, A., Shikha, F. A., Anwar, M., Hamid, A. B. A., \& Tat, H. H. (2020). The impact of coronavirus (COVID-19) on e-business in Malaysia. Asian Journal of Multidisciplinary Studies, 3(1): 85- 90.

Hasimi, M. (2020). Malaysia loses RM2.4 billion a day throughout MCO - Prime Minister. Retrieved December 10, 2021 , https://www. astroawani.com/berita-malaysia/malaysia-loses-rm24-billion-day-throughout-mco-prime-minister-241019

Jantan, M. S., Tiong, L. J., Abdul Rashid, A. A., Abdul Halim, N. A., \& Lim, Y. X. (2020). Navigating personal finance during the coronavirus pandemic. SSRN Electronic Journa/ https://doi.org/10.2139/ssrn.3690980

Lai, M. M., Lein, S. Y., Lau, S. H., \& Lai, M. L. (2016). Modeling age-friendly environment, active aging, and social connectedness in an emerging Asian economy. Journal of Aging Research, 2016, 1- 14. https://doi.org/10.1155/2016/2052380

Lim, L. L. (2020). The socioeconomic impacts of COVID-19 in Malaysia: Policy review and guidance for protecting the most vulnerable and supporting enterprises. International Labour Organization. Retrieved December 10, 2021, https://www.ilo.org/asia/publications/WCMS_751600/lang--en/index.htm

Lim, S. M., Tenk, T., Teoh, M., \& Lee, T. H. (2021). Employees' retirement saving behaviour during the Covid19 pandemic in Malaysia. International Journal of Academic Research in Business and Social Sciences, 11(3): 1099- 1116. https://doi.org/10.6007/IJARBSS/v11-i3/8855

Lloyd-Sherlock, P., Ebrahim, S., Geffen, L., \& McKee, M. (2020). Bearing the brunt of covid-19: Older people in low and middle income countries. BMJ, 1- 2. https://doi.org/10.1136/bmj.m1052

Masud. J., \& Haron, S. A. (2008). Income differences among elderly in Malaysia: A regional comparison. International Journal of Consumer Studies, 32(4): 335- 340. https://doi.org/10.1111/j.1470-6431.2008.00674.x

Matthews, R. J., Smith, L. K., Hancock, R. M., Jagger, C., \& Spiers, N. A. (2005). Socioeconomic factors associated with the onset of disability in older age: A longitudinal study of people aged 75 years and over. Social Science \& Medicine, 61(7): 1567- 1575. https://doi.org/10.1016/j.socscimed.2005.02.007

Ministry of Finance Malaysia. (2021). 55th LAKSANA Report. Retrieved December 5, 2021, https://pre2020.treasury.gov.my/flipbook/laksana55-en/

Ministry of Health. (2021). Situasi Terkini COVID-19 di Malaysia 06 JUN 2021. Retrieved December 7, 2021 http://covid19.moh.gov.my/terkini/2021/06/situasi-terkini-covid-19-di-malaysia-06062021

Mirowsky, J., \& Ross, C. E. (1998). Education, personal control, lifestyle and health: A human capital hypothesis. Research on Aging, 20(4): 415- 449. https://doi.org/10.1177/0164027598204003

Mustaffa, N., Lee, S.-Y., Nawi, S. N. M., Rahim, M. J. C., Chee, Y. C., Besari, A. M., \& Lee, Y. Y. (2020). COVID-19 in the elderly: A Malaysian perspective. Journal of Global Health, 10(2): 1- 4. https://doi.org/10.7189/jogh.10.020370

Ooi, P. B., Ong, D. L. T., Peh, S. C., Ismail, S. F., Paramanathan, S. A. M. S., Lee, A. S. H., Soon, L. K., \& Chan, N. N. (2021). Active aging, psychological well-being and quality of life of elderly and pre-elderly Malaysians during movement control periods. Educational Gerontology, 47(8): 353- 368. https://doi.org/10.1080/03601277.2021.1983295

Pazim, KH., Mahmud, R., Yee, B. L. F., Fabeil, N. F., Langgat, J., Ayob, N., \& Nordin, MN. (2021). The impact of CoVID-19 pandemic on Malaysian senior citizens: A review. International Journal of Aquatic Science, 12(1), 186- 192.

Povera, A. (2020). RM25 million set aside for vulnerable groups. New Straits Times. Retrieved December 10, 2021 , https://www.nst.com.my/news/nation/2020/03/578706/rm25-million-set-aside-vulnerablegroups 


\section{Khan et al.}

Rahman, N. L. A., \& Shafiai, N. I. A. (2021). Modelling financial wellbeing among young employees in Malaysia during Movement Control Order (MCO). Jurnal Intelek, 16(1): 183- 189. https://doi.org/10.24191/ji.v16i1.379

Rivan, N. F. M., Shahar, S., Singh, D. K. A., Ibrahim, N., Ludin, A. F. M., Yahya, H. M., Sakian, N. I. M., Mahadzir, H., Subramaniam, P., \& Kamaruddin, M. Z. A. (2021). Mediation effect of coping strategies on general psychological health among middle-aged and older adults during the COVID-19 pandemic. Aging \& Mental Health, 1-9. https://doi.org/10.1080/13607863.2021.1972281

Ross, C. E., \& Broh, B. A. (2000). The roles of self-esteem and the sense of personal control in the academic achievement process. Sociology of Education, 73(4): 270- 284. https://doi.org/10.2307/2673234

Ross C.E., \& Sastry J. (1999) The Sense of Personal Control. In: Aneshensel C.S., Phelan J.C. (eds) Handbook of the Sociology of Mental Health. Handbooks of Sociology and Social Research. Springer, Boston, MA. https://doi.org/10.1007/0-387-36223-1_18

Ross, M. (1989). Relation of implicit theories to the construction of personal histories. Psychological Review, 96(2): $341-357$. https://doi.org/10.1037/0033-295X.96.2.341

Sandanasamy, F., Paavilainen, M., \& Baruah, N. (2020). COVID-19: Impact on migrant workers and country response in Malaysia. International Labour Organization. Retrieved December 7, 2021, https://www.ilo.org/asia/publications/issuebriefs/WCMS_741512/lang--en/index.htm

Shah, A. U. M., Safri, S. N. A., Thevadas, R., Noordin, N. K., Abd Rahman, A., Sekawi, Z., Ideris, A., \& Sultan, M. T. H. (2020). COVID-19 outbreak in Malaysia: Actions taken by the Malaysian government. International Journal of Infectious Diseases, 97, 108- 116. https://doi.org/10.1016/j.ijid.2020.05.093

Shakeel, S., Hassali, M. A. A., \& Naqvi, A. A. (2020). Health and economic impact of COVID-19: Mapping the consequences of a pandemic in Malaysia. The Malaysian Journal of Medical Sciences, 27(2): 159-164. https://doi.org/10.21315/mjms2020.27.2.16

Social Wellbeing Research Centre. (2021). Malaysia Ageing and Retirement Survey (MARS) Wave 1 - 2018/2019. Retrieved December 4, 2021, https://doi.org/10.1007/978-3-319-69892-2_344-1

Ubaidillah, M., Ismail, M. A., \& Noor, M. A. M. (2020). The waqf integrated financial instrument of pension model in Malaysian social security: A conceptual proposition. The Journal of Muamalat and Islamic Finance Research, 17(1): $33-55$. https://doi.org/10.33102/jmifr.v17i1.259

UN News. (2020). 'Rights and dignity' of older people must be respected during COVID-19 and beyond. Retrieved December 8 , 2021, https://news.un.org/en/story/2020/05/1063052

United Nations Development Programme. (2020). UNDP Rapid Assessment on Household Income Survey (RaHIS). Retrieved December 5, 2021, https://www.my.undp.org/content/malaysia/en/home/news-centre/pressreleases/undp-malaysiacontributes--202-000-to-malaysias-covid-19-fund.html

United Nations. (2020). Policy Brief: The impact of COVID-19 on older persons. Retrieved December 5, 2021, https://unsdg.un.org/sites/default/files/2020-05/Policy-Brief-The-Impact-of-COVID-19-on-Older-Persons.pdf

World Bank. (2020). East Asia and Pacific in the time of COVID-19. Retrieved December 5, 2021, https://doi.org/10.1596/978$1-4648-1565-2$

World Health Organization. (2020). Advice on the use of masks in the context of COVID-19: Interim guidance. Retrieved December 3, 2021, https://doi.org/apps.who.int/iris/handle/10665/332293.

Xie, B., Charness, N., Fingerman, K., Kaye, J., Kim, M. T., \& Khurshid, A. (2020). When going digital becomes a necessity: Ensuring older adults' needs for information, services, and social inclusion during COVID-19. Journal of Aging \& Social Policy, 32(4- 5): 460- 470. https://doi.org/10.1080/08959420.2020.1771237

Xue, R., Gepp, A., O'Neill, T. J., Stern, S., \& Vanstone, B. J. (2020). Financial well-being amongst elderly Australians: The role of consumption patterns and financial literacy. Accounting and Finance, 60(4): 4361- 4386. https://doi.org/10.1111/acfi.12545

Yeo, J., \& Lee, Y. G. (2019). Understanding the association between perceived financial well-being and life satisfaction among older adults: Does social capital play a role? Journal of Family and Economic Issues, 40(4): 592- 608. https://doi.org/10.1007/s10834-019-09634-2

Zainul, M. (2020). MIER warns of recession if partial lockdown extended. Retrieved December 10, 2021, https://www.theedgemarkets.com/article/mier-warns-recession-if-partial-lockdown-extended

\section{ACKNOWLEDGMENT}

The corresponding author gratefully acknowledges the Universiti Tunku Abdul Rahman (UTAR), Malaysia for supporting this study under the project number IPSR/RMC/UTARRF/2019-C2/K03. 


\begin{tabular}{|c|c|c|c|}
\hline Author & Title & Purpose & Findings \\
\hline $\begin{array}{l}\text { Aziz et al. } \\
(2021)\end{array}$ & $\begin{array}{l}\text { Improving Social } \\
\text { Security among Older } \\
\text { Persons in Malaysia } \\
\text { During Covid-19 by } \\
\text { Applying Best Practices } \\
\text { from Other Countries }\end{array}$ & $\begin{array}{l}\text { To examine the underlying gaps in the } \\
\text { implementation of pension retirement in } \\
\text { our country and draw the best practices } \\
\text { from other countries. }\end{array}$ & $\begin{array}{l}\text { Taking proactive measures, } \\
\text { such as saving early and } \\
\text { receiving financial security } \\
\text { education, can help to ensure a } \\
\text { better life after retirement. }\end{array}$ \\
\hline $\begin{array}{l}\text { Rivan et } \\
\text { al. }(2021)\end{array}$ & $\begin{array}{l}\text { Mediation effect of } \\
\text { coping strategies on } \\
\text { general psychological } \\
\text { health among middle- } \\
\text { aged and older adults } \\
\text { during the COVID-19 } \\
\text { pandemic }\end{array}$ & $\begin{array}{l}\text { To assess general psychological health, } \\
\text { associated factors and the potential of } \\
\text { coping strategies as a mediator for middle- } \\
\text { aged and older Malaysian adults during the } \\
\text { COVID-19 pandemic. }\end{array}$ & $\begin{array}{l}\text { Middle-aged and older adults in } \\
\text { Malaysia had good } \\
\text { psychological health during the } \\
\text { COVID-19 pandemic, } \\
\text { especially when living with } \\
\text { family, physically active, and } \\
\text { having good subjective well- } \\
\text { being. }\end{array}$ \\
\hline $\begin{array}{l}\text { Ooi et al. } \\
(2021)\end{array}$ & $\begin{array}{l}\text { Active aging, } \\
\text { psychological well- } \\
\text { being and quality of life } \\
\text { of elderly and pre- } \\
\text { elderly Malaysians } \\
\text { during movement } \\
\text { control periods }\end{array}$ & $\begin{array}{l}\text { To examine the perception of Malaysians } \\
\text { about active aging during the period of } \\
\text { Movement Control Orders (MCOs) in } \\
\text { Malaysia. }\end{array}$ & $\begin{array}{l}\text { Psychological well-being is the } \\
\text { leading factor that positively } \\
\text { affects the quality of life, } \\
\text { followed by social support and } \\
\text { networking, daily living } \\
\text { activities and financial } \\
\text { planning. }\end{array}$ \\
\hline $\begin{array}{l}\text { Pazim et } \\
\text { al. }(2021)\end{array}$ & $\begin{array}{l}\text { The Impact of Covid-19 } \\
\text { Pandemic On Malaysian } \\
\text { Senior Citizens: A } \\
\text { Review }\end{array}$ & $\begin{array}{l}\text { To analyses the influence of the COVID- } \\
19 \text { on older people in the context of } \\
\text { exploring the prospects for their social and } \\
\text { economic independence, emphasizing the } \\
\text { importance of promoting efficient supports } \\
\text { and networks to ensure the well-being of } \\
\text { these vulnerable older people during a } \\
\text { pandemic. }\end{array}$ & $\begin{array}{l}\text { Older adults experienced a } \\
\text { variety of obstacles, including } \\
\text { increasing time spent at home, } \\
\text { decreased physical engagement } \\
\text { with other family members and } \\
\text { friends, decreased social } \\
\text { participation. }\end{array}$ \\
\hline $\begin{array}{l}\operatorname{Lim} \text { et al. } \\
(2021)\end{array}$ & $\begin{array}{l}\text { Employees' Retirement } \\
\text { Saving Behavior During } \\
\text { The Covid-19 Pandemic } \\
\text { in Malaysia }\end{array}$ & $\begin{array}{l}\text { To assess whether income level, economic } \\
\text { condition, saving behavior and retirement } \\
\text { goal clarity affect employees' retirement } \\
\text { saving behavior during the COVID-19 } \\
\text { pandemic in Malaysia. }\end{array}$ & $\begin{array}{l}\text { Financial education for children } \\
\text { is important for successful } \\
\text { financial retirement planning } \\
\text { during downturns and } \\
\text { pandemics. }\end{array}$ \\
\hline $\begin{array}{l}\text { Foong et } \\
\text { al. }(2021)\end{array}$ & $\begin{array}{l}\text { Relationship between } \\
\text { financial well-being, life } \\
\text { satisfaction, and } \\
\text { cognitive function } \\
\text { among low-income } \\
\text { community-dwelling } \\
\text { older adults: the } \\
\text { moderating role of sex }\end{array}$ & $\begin{array}{l}\text { To examine the moderating effect of sex on } \\
\text { the relationships between financial well- } \\
\text { being, life satisfaction, and cognitive } \\
\text { function among low-income older adults. }\end{array}$ & $\begin{array}{l}\text { Poverty eradication initiatives } \\
\text { targeting low-income older } \\
\text { adults should be implemented to } \\
\text { sustain life satisfaction and } \\
\text { cognitive function. }\end{array}$ \\
\hline $\begin{array}{l}\text { Chung et } \\
\text { al. (2020) }\end{array}$ & $\begin{array}{l}\text { The repercussions of } \\
\text { covid-19 pandemic on } \\
\text { the wellbeing of older } \\
\text { people in Malaysia: A } \\
\text { literature review }\end{array}$ & $\begin{array}{l}\text { To provide focused research on the } \\
\text { repercussions of this pandemic on the older } \\
\text { people in Malaysia. }\end{array}$ & $\begin{array}{l}\text { The impacts of the pandemic } \\
\text { COVID- } 19 \text { on older people are } \\
\text { still significant. }\end{array}$ \\
\hline
\end{tabular}

